\title{
Annotatie bij Gemeenschappelijk Hof van Justitie van Aruba, Curaçao, Sint Maarten en van Bonaire, Sint Eustatius en Saba 31 oktober 2019, ECLI:NL:OGHACMB:2019:184
}

\author{
Prof. mr. P. Bovend'Eert*
}

Gemeenschappelijk Hof van Justitie van Aruba, Curaçao, Sint Maarten en van Bonaire, Sint Eustatius en Saba

31 oktober 2019, zittingsplaats Curaçao, CUR2019H00367

(mr. J.J. Verhoeven, voorzitter, mrs. A.J.H. van Suilen, M. Soffers)

\section{Wraking toegewezen.}

(art. 34 Lar; art. 6 EVRM)

De wrakingskamer stelt voorop dat het enkele feit dat een rechter een voorlopig oordeel geeft tijdens de behandeling van een zaak, niet zonder meer de vrees voor vooringenomenheid rechtvaardigt. Echter nu de rechter in stellige bewoordingen en, zoals is gebleken tijdens de mondelinge behandeling van het wrakingsverzoek, weloverwogen zijn mening heeft gegeven over een rechtsvraag die in de Oostpuntzaak speelt tijdens de behandeling van een andere zaak (de HNO-zaak), waarin verzoekers [verzoekers $3 \mathrm{t} / \mathrm{m}$ 5] niet als partij optraden, heeft bij verzoekers in het onderhavige geval een - geobjectiveerde - vrees van vooringenomenheid kunnen ontstaan. Door deze gang van zaken kan bij verzoekers immers de indruk zijn gewekt dat de rechter zijn oordeel over de zaak reeds voor de behandeling had gevormd en niet openstond voor argumenten die in een andere richting wijzen. Dit geldt te meer, nu niet blijkt van enige noodzaak voor de rechter om zich voorlopig oordelend uit te laten over een rechtsvraag in de Oostpuntzaak buiten de aanwezigheid van verzoekers [verzoekers $3 \mathrm{t} / \mathrm{m}$ 5] Dat de rechter ook te kennen heeft gegeven dat de rechtsvraag twee dagen later op vrijdag 18 okto-

* Prof.mr. P. Bovend'Eert is als hoogleraar staatsrecht verbonden aan de Radboud Universiteit Nijmegen.

ber 2019 zou worden besproken, is onvoldoende om deze vrees weg te nemen.

\section{Partijen}

1 de Regering van Curaçao,

2 de Staten van Curaçao, te Curaçao, hierna respectievelijk ook te noemen: de regering en de staten, gemachtigden: mr. A.C. van Hoof en mw. G. Hollander,

en

3 [verzoeker 3],

4 [verzoeker 4],

5 [verzoeker 5], te Curaçao,

hierna ook te noemen: [verzoekers $3 \mathrm{t} / \mathrm{m} \mathrm{5}$ ], gemachtigden: mrs. M.G. Woudstra en P. Blom, verzoekers.

\section{De procedure}

1.1 Het verloop van de procedure blijkt onder meer uit:

- $\quad$ het wrakingsverzoek, ingediend op 18 oktober 2019;

- de schriftelijke reactie van de rechter mr. D. Haan van 21 oktober 2019;

- de pleitaantekeningen van partijen;

- de griffiersaantekeningen van de zaak CUR201400565.

1.2 Het wrakingsverzoek is op 24 oktober 2014 in het openbaar behandeld door de meervoudige 
kamer voor de behandeling van wrakingszaken (verder: de

wrakingskamer). Bij de mondelinge behandeling zijn verschenen de gemachtigden van verzoekers, de rechter en de gemachtigde van wederpartij in de bodemzaak, mr. Henriquez.

1.3 De uitspraak is bepaald op heden.

\section{Het verzoek}

2.1 Het verzoek tot wraking is gericht tegen de rechter mr. D. Haan als behandelend rechter, in de zaken met zaaknummers CUR201700200 en CUR201700068.

2.2 Namens verzoekers is aan het verzoek tot wraking ten grondslag gelegd dat de rechter, tijdens de zaak HNO op 16 oktober 2019 reeds een oordeel heeft gegeven over de totstandkoming van de Landsverordening herziening Oostpunt (de Landsverordening), terwijl de zaak Oostpunt nog onder de rechter is en er nog geen mondelinge behandeling heeft plaatsgevonden. Die behandeling zou op 18 oktober 2019 plaatsvinden. Tevens heeft de rechter de zaak Oostpunt ten onrechte meerdere keren ter sprake gebracht tijdens de zitting van de zaak $\mathrm{HNO}$, wat indruist tegen een juiste procesrechtelijke gang van zaken. $\mathrm{Nu}$ de rechter voorafgaand aan de inhoudelijke behandeling van de zitting - nota bene tijdens een andere niet gerelateerde zitting - zijn standpunt heeft gegeven over een voor de zaak Oostpunt relevante rechtsvraag, is de vrees gerechtvaardigd dat de rechter niet onpartijdig staat in de aanhangige procedure, althans dat in ieder geval de schijn van vooringenomenheid is gewekt.

2.3 De rechter berust niet in de wraking. In zijn schriftelijke reactie stelt hij zich op het standpunt dat de eerdere beantwoording van een rechtsvraag, waarbij enig partijbelang geen enkele rol heeft gespeeld, niet kan leiden tot het oordeel van vrees voor partijdigheid in zaken waarin de rechtsvraag opnieuw beantwoord moet worden door dezelfde rechter. De bewering dat de rechter een voorschot heeft genomen op zijn aanstaande oordeel is onjuist, omdat hij partijen in de zaak HNO de gelegenheid heeft gegeven zich schriftelijk nader uit te laten, mede over de rechtsvraag. Hij heeft tijdens de zaak HNO slechts zijdelings aan de zaak Oostpunt gerefereerd, wat overigens nogal voor de hand lag, omdat mr. Woudstra en mevrouw Hollander van het betrokken ministerie en overigens ook mr. Henriquez in de zaak Oostpunt zouden optreden.

\section{De beoordeling}

3.1 Op grond van artikel 34, lid 1 Landsverordening administratieve rechtspraak kan de zittende rechter door partijen worden gewraakt op grond van feiten of omstandigheden die het vormen van een onpartijdig oordeel zouden belemmeren. Uitgangspunt daarbij is dat de rechter uit hoofde van zijn aanstelling wordt vermoed onpartijdig te zijn, tenzij zich een uitzonderlijke omstandigheid voordoet, die een zwaarwegende aanwijzing oplevert voor het oordeel dat een rechter jegens een partij bij een geding een vooringenomenheid koestert. De vrees dat dit het geval zal zijn, dient objectief gerechtvaardigd te zijn. Dat betekent dat sprake moet zijn van concrete feiten en omstandigheden waaruit objectief de vrees voor partijdigheid van de rechter kan worden afgeleid. Daarnaast kan er onder omstandigheden reden zijn voor wraking, indien geheel afgezien van de persoonlijke opstelling van de rechter in de hoofdzaak de bij een partij bestaande vrees voor partijdigheid van die rechter objectief gerechtvaardigd is, waarbij rekening moet worden gehouden met uiterlijke schijn.

3.2 Naar het oordeel van de wrakingskamer heeft bij verzoekers in het onderhavige geval een - geobjectiveerde - vrees van vooringenomenheid kunnen ontstaan.

Gelet op de zich in dossier bevindende stukken en het verhandelde ter zitting stelt de wrakingskamer vast dat tijdens de behandeling van de zaak HNO de rechter gerefereerd heeft aan de zaak Oostpunt, welke zaak op een later moment door de rechter behandeld zou worden. Verzoekers hebben in het verzoekschrift opgenomen dat de rechter daarbij onder meer heeft gezegd: 
"In de zaak Oostpunt is het ontwikkelingsplan vastgesteld bij landsverordening, naar mijn mening is dat niet juist maar dient dit te geschieden bij Lb Ham, maar dat zullen wij vrijdag a.s. samen bespreken."

De rechter heeft desgevraagd tijdens de mondelinge behandeling verklaard dat hij zich tijdens de behandeling van de HNO-zaak in dergelijke bewoordingen heeft uitgelaten, maar dat hij daarmee geen oordeel heeft gegeven over de totstandkoming van de Landsverordening omdat partijen in die HNO-zaak nog de gelegenheid hadden zich daarover uit te laten.

De wrakingskamer stelt voorop dat het enkele feit dat een rechter een voorlopig oordeel geeft tijdens de behandeling van een zaak, niet zonder meer de vrees voor vooringenomenheid rechtvaardigt. Echter nu de rechter in stellige bewoordingen en, zoals is gebleken tijdens de mondelinge behandeling van het wrakingsverzoek, weloverwogen zijn mening heeft gegeven over een rechtsvraag die in de Oostpuntzaak speelt tijdens de behandeling van een andere zaak (de HNO zaak), waarin verzoekers [verzoekers $3 \mathrm{t} / \mathrm{m}$ 5] niet als partij optraden, heeft bij verzoekers in het onderhavige geval een - geobjectiveerde - vrees van vooringenomenheid kunnen ontstaan. Door deze gang van zaken kan bij verzoekers immers de indruk zijn gewekt dat de rechter zijn oordeel over de zaak reeds voor de behandeling had gevormd en niet openstond voor argumenten die in een andere richting wijzen. Dit geldt te meer, nu niet blijkt van enige noodzaak voor de rechter om zich voorlopig oordelend uit te laten over een rechtsvraag in de Oostpuntzaak buiten de aanwezigheid van verzoekers [verzoekers $3 \mathrm{t} / \mathrm{m}$ 5] Dat de rechter ook te kennen heeft gegeven dat de rechtsvraag twee dagen later op vrijdag 18 oktober 2019 zou worden besproken, is onvoldoende om deze vrees weg te nemen.

3.3 Het wrakingsverzoek is, gelet op het voorgaande, gegrond en zal mitsdien worden toegewezen.

\section{Beslissing}

De wrakingskamer:

4.1 wijst het verzoek tot wraking van mr. D. Haan toe;

4.2 bepaalt dat de procedure verder zal worden behandeld door een andere rechter en beveelt dat het onderzoek ter zitting wordt voortgezet op een nader te bepalen tijdstip;

4.3 draagt de griffier van de wrakingskamer op deze beslissing toe te zenden aan verzoekers, mr. Henriquez, en aan de rechter.

\section{Noot}

De beslissing van de wrakingskamer van het Gemeenschappelijk Hof van Justitie (hierna: Hof) betreft een bijzondere situatie waarin de onpartijdigheid van een rechter door bepaalde uitlatingen van de rechter ter zitting ter discussie wordt gesteld. In de onderhavige zaak doen gemachtigden van een procespartij tijdens de behandeling van een zaak (zaak Oostpunt) een wrakingsverzoek dat betrekking heeft op uitlatingen van de rechter ter zitting in een eerdere zaak (HNO-zaak), die enkele dagen daarvoor door de rechter behandeld is ten overstaan van dezelfde procespartij. Beide zaken staan overigens los van elkaar. De uitlating heeft betrekking op de beantwoording van een rechtsvraag over een landsverordening. Volgens de procespartij die om wraking verzoekt, zou de rechter vooruitlopend op de nog te behandelen zaak in de daaraan voorafgaande zaak al zijn standpunt hebben kenbaar gemaakt over de betreffende rechtsvraag. De rechter berust niet in de wraking en stelt dat hij niet een voorschot heeft genomen op zijn aanstaande oordeel.

De wrakingskamer van het Hof is van oordeel dat in het onderhavige geval bij de verzoekers tot wraking een geobjectiveerde vrees van vooringenomenheid heeft kunnen ontstaan. Volgens verzoekers heeft de rechter in de HNO-zaak het volgende verklaard: 'In de zaak Oostpunt is het ontwikkelingsplan vastgesteld bij landsverordening, naar mijn mening is dat niet juist, maar dient dit te geschieden bij Lb Ham, 
maar dat zullen we vrijdag a.s. samen bespreken.' De rechter stelt dat hij daarmee geen oordeel heeft gegeven, omdat partijen nog de gelegenheid hadden zich daarover uit te spreken.

De wrakingskamer stelt dat het enkele feit dat een rechter een voorlopig oordeel geeft niet zonder meer de vrees voor vooringenomenheid rechtvaardigt. Maar omdat de rechter in dit geval in stellige bewoordingen, weloverwogen zijn mening heeft gegeven over de rechtsvraag, heeft een geobjectiveerde vrees van vooringenomenheid kunnen ontstaan. Dat de rechter heeft aangegeven dat de rechtsvraag alsnog besproken zou worden, is volgens de wrakingskamer onvoldoende om deze vrees weg te nemen. De wrakingskamer wijst het wrakingsverzoek op deze gronden toe. Aan het vereiste van rechterlijke onpartijdigheid is niet voldaan. De uitleg van het vereiste van rechterlijke onpartijdigheid bij wraking en verschoning wordt, zoals bekend, sterk ingekleurd door EHRM-jurisprudentie over artikel 6 EVRM (independent and impartial tribunal), hoewel de procedure van wraking en verschoning als zodanig buiten de werkingssfeer van artikel 6 EVRM valt. De Hoge Raad pleegt zich nadrukkelijk te oriënteren op de jurisprudentie van het EHRM. In HR 30 november 1990, NJ 1992/94, bijvoorbeeld, overweegt de Hoge Raad dat wraking het middel is dat partijen ten dienste staat om het hun ingevolge artikel 6 EVRM toekomende recht op een onpartijdige rechter af te dwingen.

In het voetspoor van het EHRM maakt de Hoge Raad een onderscheid tussen subjectieve en objectieve onpartijdigheid. In de onderhavige zaak maakt de wrakingskamer van het Hof eveneens dit onderscheid. De subjectieve onpartijdigheid heeft betrekking op de persoonlijke instelling en overtuiging van de rechter in een bepaalde zaak. Indien bij de rechter sprake is van vooringenomenheid ten opzichte van een van de partijen of ten opzichte van de zaak, is de rechterlijke onpartijdigheid niet gewaarborgd. Een dergelijke partijdigheid wordt blijkens de praktijk in de jurisprudentie niet snel aangenomen. De Hoge Raad overweegt in navolging van het EHRM dat mede op grond van de voor rechters geldende benoembaarheidsvereisten en selectiecriteria moet worden aangenomen, behoudens bewijs van het tegendeel, dat de rechter zich bij zijn taakvervulling los weet te maken van eventuele vooringenomenheid (HR 30 november 1990, NJ 1992/94; EHRM 24 mei 1989, ECHR Series A, nr. 154, NJ 1990/627 (Hauschildt)). De rechter wordt vermoed onpartijdig te zijn, tenzij zich uitzonderlijke omstandigheden voordoen die zwaarwegende aanwijzingen opleveren voor het oordeel dat een rechter vooringenomenheid koestert (HR 15 april 1997, NJ 1997/535). De vrees voor subjectieve partijdigheid moet objectief gerechtvaardigd zijn (zie hiervoor Hauschildt).

De objectieve onpartijdigheid houdt in dat er los van de persoonlijke overtuiging van de rechter voldoende waarborgen zijn om bij de procespartijen iedere objectief gerechtvaardigde twijfel aan zijn onpartijdigheid uit te sluiten. Hier wordt het subjectieve element van vooringenomenheid geobjectiveerd. Er moet gerechtvaardigde twijfel zijn, bijvoorbeeld doordat een rechter in opeenvolgende fasen van de procedure een oordeel geeft. Voor de objectieve onpartijdigheid geldt een lagere bewijsdrempel dan voor de subjectieve onpartijdigheid.

De objectieve onpartijdigheid is in het onderhavige geval niet in het geding, nu het niet gaat om optreden van de rechter in opeenvolgende fasen van een procedure.

De wrakingskamer stelt terecht de vraag aan de orde of sprake is van een geobjectiveerde vrees van vooringenomenheid door de uitlatingen van de rechter ter zitting.

Uit de overigens zeer casuïstische rechtspraak van het EHRM en ook uit de rechtspraak van de Hoge Raad is af te leiden dat slechts zelden wordt aangenomen dat een (beroeps)rechter vanwege zijn gedrag bij de behandeling van een zaak vooringenomen is en dat er voor een procespartij een geobjectiveerde vrees van vooringenomenheid ontstaat (M. Kuijer, The blindfold of lady justice (diss Leiden), Nijmegen: Wolf Legal Publishers 2004; P. Smits, Artikel 6 EVRM en de civiele procedure, Deventer: Kluwer 2008). Zo kan een rechter bijvoorbeeld niet als partijdig worden aangemerkt enkel op de grond dat uit zijn vragen ter zitting blijkt dat hij op basis van het 
dossier zich een eerste oordeel over de zaak heeft gevormd (EHRM 8 maart 1998, 12002/86 (Grant/ $V K))$.

In de onderhavige zaak gaat het om een voorlopig oordeel dat de rechter tijdens de behandeling van een zaak geeft. Terecht stelt de wrakingskamer dat zo'n voorlopig oordeel op zichzelf niet de vrees van vooringenomenheid rechtvaardigt. Blijkens de jurisprudentie van het EHRM behoeft zo'n voorlopig oordeel van de rechter op zichzelf niet per se afbreuk te doen aan de rechterlijke onpartijdigheid (EHRM 7 januari 1991, 14063/88 (Jensen/Denemarken)). Volgens de wrakingskamer is echter in dit geval sprake van 'stellige bewoordingen' en weloverwogen een mening geven door de rechter, waardoor alsnog de onpartijdigheid in het geding is. In dat laatste kan ik de wrakingskamer niet goed volgen. Beslissend lijkt mij dat vaststaat dat de rechter slechts een voorlopig oordeel heeft gegeven en daarbij uitdrukkelijk heeft gezegd dat er nog over gesproken moet worden. De ene rechter zal dat misschien wat voorzichtiger doen dan de andere rechter die wellicht wat stelliger is. Maar de strekking is dat slechts een voorlopig oordeel wordt gegeven. Dat is denk ik beslissend. Uitgangspunt moet zijn dat de rechter openstaat voor wijziging van zijn aanvankelijke opvatting, wanneer hij op grond van de stellingen van partijen de feiten vaststelt en het recht toepast. Zou men dit uitgangspunt miskennen, dan zou de omstandigheid dat de rechter zijn eerdere jurisprudentie in latere vergelijkbare zaken toepast, aanleiding zijn te twijfelen aan de onpartijdigheid van de rechter. Dat kan niet de bedoeling zijn

De conclusie is dat de wrakingskamer in de onderhavige zaak mijns inziens te streng geoordeeld heeft over de onpartijdigheid van de betrokken rechter. 